\title{
HUBUNGAN DIABETES MELITUS TERHADAP KEJADIAN SINDROMA TEROWONGAN KARPAL DI RS BETHESDA YOGYAKARTA
}

\author{
Dyah Wulaningsih Retno Edi, Rizaldy Taslim Pinzon, \\ Esdras Ardi Pramudita \\ Fakultas Kedokteran Universitas Kristen Duta Wacana \\ Rumah Sakit Bethesda
}

Korespondensi: medidoc2002@yahoo.com

\begin{abstract}
ABSTRAK
Latar Belakang: Sindroma Terowongan Karpal (STK) merupakan neuropati jebakan yang paling sering dijumpai. Terdapat berbagai faktor risiko yang berpotensi meningkatkan terjadinya STK, contohnya diabetes melitus. Penelitian sebelumnya menyebutkan bahwa STK banyak terkait dengan diabetes melitus namun hasilnya masih kontroversial.

Tujuan: Penelitian ini bertujuan untuk mengetahui hubungan antara diabetes melitus terhadap kejadian sindroma terowongan karpal di Rumah Sakit Bethesda Yogyakarta.

Metode: Studi potong lintang menggunakan data rekam medis pasien saraf Rumah Sakit Bethesda Yogyakarta. Data yang diperoleh kemudian diuji dengan analisis univariat yang kemudian dilanjutkan dengan analisis bivariat dan multivariat dengan uji regresi logistik

Hasil: Data diperoleh dari 222 sampel (134 perempuan dan 88 laki-laki) dengan 95 pasien STK dan 127 pasien non STK. Riwayat diabetes melitus terdapat pada $17(17,9 \%)$ pasien kelompok STK dan 31 (24,4\%) pasien pada kelompok non STK. Didapatkan hasil bahwa diabetes melitus tidak memiliki hubungan terhadap kejadian STK (RO: 0,68, IK 95\%=0,35 - 1,31, $p=0,243$ ), namun pekerjaan sebagai ibu rumah tangga merupakan faktor risiko independen dari STK (RO: 3,34, IK 95\%=1,36 $-8,24, p=0,009)$.

Kesimpulan: Pekerjaan sebagai ibu rumah tangga meningkatkan kejadian STK sebesar 3,3 kali lipat dibanding pekerjaan lain. Diabetes melitus tidak menunjukkan hubungan yang signifikan terhadap kejadian STK di RS Bethesda Yogyakarta.
\end{abstract}

Kata Kunci: sindroma terowongan karpal, STK, faktor risiko, diabetes melitus 


\title{
ASSOCIATION BETWEEN DIABETES MELLITUS AND CARPAL TUNNEL SYNDROME IN BETHESDA HOSPITAL YOGYAKARTA
}

\author{
Dyah Wulaningsih Retno Edi, Rizaldy Taslim Pinzon, \\ Esdras Ardi Pramudita \\ Medical Faculty of Duta Wacana Christian University \\ Bethesda Hospital Yogyakarta \\ Correspondence: medidoc2002@yahoo.com
}

\begin{abstract}
Background: Carpal Tunnel Syndrome (CTS) is the most frequently encountered entrapment neuropathy. There are various risk factors that could potentially increase the occurrence of CTS, for example diabetes mellitus. Previous studies have shown that CTS is related to diabetes mellitus, but the results are still controversial.

Objective: This research objective is to determine the association between diabetes mellitus and carpal tunnel syndrome in Bethesda Hospital Yogyakarta.

Methods: Cross sectional study using data from medical records of Bethesda Hospital Yogyakarta in the period from January 2013 to June 2014. The data was analyzed using univariate and bivariate analysis followed by chi-square test and multivariate logistic regression.

Results: Data were obtained from 222 samples (134 female and 88 male) with 95 CTS patients and 127 non CTS patients. History of diabetes mellitus was found in 17 (17,9\%) patients in the CTS group and 31 (24,4\%) patients in non CTS group. Based on the results, diabetes mellitus was not associated with CTS (OR: 0,68, 95\%CI=0,35$1,31, p=0,243)$ but occupation as a housewife was independent risk factor to CTS (OR: 3,34, 95\% CI=1,36-8,24, $p=0,009$ ).

Conclusion: Occupation as a housewife increase the incidence of CTS by 3,3 times compared than other occupation. Diabetes mellitus was not associated with the incidence of CTS in Bethesda Hospital Yogyakarta.
\end{abstract}

Keywords: carpal tunnel syndrome, CTS, risk factors, diabetes mellitus 


\section{PENDAHULUAN}

Sindroma Terowongan karpal (STK) merupakan neuropati jebakan yang paling sering dijumpai. Penyakit ini biasa timbul di usia pertengahan dan wanita lebih banyak menderita daripada pria. ${ }^{1}$ Penyakit ini menyebabkan rasa nyeri, dapat pula membatasi fungsifungsi pergelangan tangan sehingga dapat menurunkan produktivitas dan pengeluaran meningkat dalam bentuk biaya pengobatan. Rasa sakit karena STK bervariasi dari rasa sedikit tidak nyaman sampai kondisi tidak mampu mengerjakan pekerjaan dengan tangan. ${ }^{2}$

Beberapa faktor utama yang berpotensi meningkatkan risiko STK adalah usia lanjut, jenis kelamin wanita, adanya obesitas dan diabetes. Faktor risiko lainnya adalah kehamilan, pekerjaan, riwayat pada keluarga dan gerakan yang kumulatif dan repetitif. ${ }^{3}$ Etiologi STK diurutkan menurut yang paling umum adalah cedera berulang, obesitas, kehamilan, artritis, hipotiroidisme dan diabetes melitus. ${ }^{4}$ Diabetes melitus merupakan suatu kumpulan masalah anatomi dan kimiawi dari beberapa faktor dimana didapat defisiensi insulin absolut atau relatif dan gangguan fungsi insulin. ${ }^{5}$

Mekanisme STK terkait diabetes belum begitu diketahui, tetapi dua teori umum berlaku. Pertama, ketika kadar gula darah tinggi terjadi glikosilasi atau menempelnya glukosa pada protein tendon dari terowongan karpal yang menyebabkan kekakuan dan penebalan dari transverse carpal ligament. Kemungkinan kedua adalah terjadinya komplikasi diabetes yaitu polineuropati yang menyebabkan meningkatnya kerentanan terjadinya kompresi pada saraf medianus. ${ }^{6}$
Terdapat penelitian yang menyebutkan bahwa diabetes melitus bukan merupakan faktor risiko independen terhadap STK,namun juga terdapat penelitian yang menyebutkan bahwa diabetes melitus merupakan faktor risiko yang berhubungan dengan STK. ${ }^{7,8}$ Tujuan dari penelitian ini adalah untuk mengetahui adanya hubungan diabetes melitus terhadap kejadian STK terutama di RS Bethesda Yogyakarta.

\section{METODE PENELITIAN}

Penelitian ini dilakukan dengan rancangan potong lintang, yaitu penelitian analitik observasional dimana dalam penelitian ini variabel bebas (diabetes melitus) dan tergantung (sindroma terowongan karpal) dinilai secara simultan pada suatu saat (point time approach).

Penelitian ini dilakukan di RS Bethesda, Yogyakarta pada Februari 2015 dengan data diambil dari register EMG (electromyography) dan rekam medis pasien periode Januari 2013 Juni 2014. Sampel yang digunakan pada penelitian ini adalah pasien berusia 25 tahun yang dilakukan pemeriksaan EMG tangan dengan diagnosis STK dan bukan STK. Variabel yang akan dilihat adalah jenis kelamin, usia, pekerjaan, riwayat diabetes melitus, riwayat artritis reumatoid dan riwayat kehamilan pasien.

Data penelitian terlebih dahulu akan dianalisis menggunakan analisis univariat, apabila muncul dua hingga lebih variabel dependen maka akan dilanjutkan dengan analisis bivariat dengan menggunakan uji chi square dan atau analisis multivariat dengan uji regresi logistik. 


\section{Hasil}

Tabel 1. Karakteristik seluruh sampel pasien EMG tangan di RS Bethesda

\begin{tabular}{clcc}
\hline No. & \multicolumn{1}{c}{ Karakteristik } & $\mathrm{n}=222$ & $\%(100 \%)$ \\
\hline 1. Jenis kelamin & 88 & 39,6 \\
& - Laki-laki & 134 & 60,4 \\
\hline - Perempuan & & \\
\hline 2. & Usia & 58 & 26,1 \\
- $25-45$ tahun & 128 & 57,7 \\
- $46-65$ tahun & 36 & 16,2 \\
- > 66 tahun & & \\
Pekerjaan & 64 & 28,8 \\
- PNS & 91 & 41 \\
- Swasta & 18 & 8,1 \\
- Tani/Buruh & 38 & 17,1 \\
- Ibu Rumah Tangga & 11 & 5 \\
- Pedagang & & \\
Riwayat penyakit & & 21,6 \\
- Diabetes Melitus & 48 & 78,4 \\
Ya & 174 & 1,8 \\
Tidak & & 98,2 \\
- Artritis Reumatoid & 4 & 0,9 \\
Ya & 218 & \\
Tidak & & \\
- Kehamilan & 220 & \\
Ya & & \\
Tidak & & \\
\hline
\end{tabular}

Tabel 2. Karakteristik sampel pasien STK dan Non STK

\begin{tabular}{|c|c|c|c|}
\hline \multirow{2}{*}{ No. } & \multirow{2}{*}{ Karakteristik } & STK & Non STK \\
\hline & & $\mathrm{n}=95$ & $\mathrm{n}=127$ \\
\hline \multirow[t]{3}{*}{1.} & Jenis kelamin & & \\
\hline & - Laki-laki & $30(31,6 \%)$ & $58(45,7 \%)$ \\
\hline & - Perempuan & $65(68,4 \%)$ & $69(54,3 \%)$ \\
\hline \multirow[t]{4}{*}{2.} & Usia & & \\
\hline & - 25 - 45 tahun & $24(25,3 \%)$ & $34(26,8 \%)$ \\
\hline & - $46-65$ tahun & $60(63,2 \%)$ & $68(53,5 \%)$ \\
\hline & - > 66 tahun & $11(11,6 \%)$ & $25(19,7 \%)$ \\
\hline \multirow[t]{6}{*}{3.} & Pekerjaan & & \\
\hline & - PNS & $20(21,1 \%)$ & $44(34,6 \%)$ \\
\hline & - Swasta & $38(40 \%)$ & $53(41,7 \%)$ \\
\hline & - Tani/Buruh & $7 \quad(7,4 \%)$ & $11 \quad(8,6 \%)$ \\
\hline & - Ibu Rumah Tangga & $25(26,3 \%)$ & $13(10,2 \%)$ \\
\hline & - Pedagang & $5 \quad(5,3 \%)$ & $6 \quad(4,7 \%)$ \\
\hline
\end{tabular}


4. Riwayat penyakit

- Diabetes Melitus

Ya

Tidak

- Artritis Reumatoid

Ya

Tidak

- Kehamilan

Ya

Tidak
$17(17,9 \%)$

$78(82,1 \%)$

$4 \quad(4,2 \%)$

$91(95,8 \%)$

$2(2,1 \%)$

$91(95,8 \%)$
$31(24,4 \%)$

$96(75,6 \%)$

$(-)$

$127(100 \%)$

$(-)$
Hasil penelitian terhadap 222 sampel terdiri dari 95 pasien dengan diagnosis STK dan 127 pasien dengan diagnosis non STK yang diantaranya didiagnosis polineuropati, radikulopati servikal, lesi plexus brachialis dan EMG tangan dalam batas normal dengan 88 $(39,6 \%)$ pasien laki-laki dan 134 (60,4\%) pasien perempuan. Rentang usia dalam penelitian ini dibagi menjadi tiga dengan frekuensi terbanyak ada pada rentang 46-65 tahun yaitu sebanyak $128(57,7 \%)$ pasien. Dari 222 sampel sebanyak $48(21,6 \%)$ pasien memiliki riwayat diabetes melitus, terdiri dari 17 $(17,9 \%)$ pasien pada kelompok STK dan $31(24,4 \%)$ pasien pada kelompok non STK.

Tabel 3. Analisis bivariat antara variabel bebas dengan kejadian STK

\begin{tabular}{|c|c|c|c|c|c|}
\hline Variabel & $\begin{array}{l}\text { STK } \\
n=95\end{array}$ & $\begin{array}{c}\text { Non STK } \\
\mathbf{n}=\mathbf{1 2 7}\end{array}$ & RO & IK 95\% & $p$ \\
\hline $\begin{array}{l}\text { Jenis kelamin } \\
\text { - } \quad \text { Laki-laki } \\
\text { - } \quad \text { Perempuan }\end{array}$ & $\begin{array}{l}30(31,6 \%) \\
65(68,4 \%)\end{array}$ & $\begin{array}{l}58(45,7 \%) \\
69(54,3 \%)\end{array}$ & $\begin{array}{l}\text { Ref } \\
1,82\end{array}$ & $1,04-3,18$ & $0,034^{*}$ \\
\hline $\begin{array}{l}\text { Usia } \\
\text { - } \quad 25-45 \text { tahun } \\
\text { - } \quad 46-65 \text { tahun } \\
\text { - }>66 \text { tahun }\end{array}$ & $\begin{array}{ll}24 & (25,3 \%) \\
60 & (63,2 \%) \\
11 & (11,6 \%)\end{array}$ & $\begin{array}{ll}34 & (26,8 \%) \\
68 & (53,5 \%) \\
25 & (19,7 \%)\end{array}$ & $\begin{array}{l}\text { Ref } \\
1,25 \\
0,62\end{array}$ & $\begin{array}{l}0,64-2,46 \\
0,23-1,64\end{array}$ & $\begin{array}{l}0,485 \\
0,291\end{array}$ \\
\hline $\begin{array}{l}\text { Pekerjaan } \\
\text { - } \quad \text { PNS } \\
\text { - } \quad \text { Swasta } \\
\text { - } \quad \text { Tani/Buruh } \\
\text { - } \text { Ibu Rumah Tangga } \\
\text { - } \text { Pedagang }\end{array}$ & $\begin{aligned} 20 & (21,1 \%) \\
38 & (40 \%) \\
7 & (7,4 \%) \\
25 & (26,3 \%) \\
5 & (5,3 \%)\end{aligned}$ & $\begin{array}{c}44(34,6 \%) \\
53(41,7 \%) \\
11(8,6 \%) \\
13(10,2 \%) \\
6(4,7 \%)\end{array}$ & $\begin{array}{l}\text { Ref } \\
1,58 \\
1,40 \\
4,23 \\
1,83\end{array}$ & $\begin{array}{c}0,76-3,27 \\
0,41-4,69 \\
1,66-10,92 \\
0,42-7,94\end{array}$ & $\begin{array}{r}0,183 \\
0,542 \\
0,001^{*} \\
0,489\end{array}$ \\
\hline
\end{tabular}


Riwayat penyakit

- Diabetes Melitus

Ya

Tidak

- Artritis Reumatoid Ya

Tidak

- Kehamilan

Ya

Tidak
$17(17,9 \%)$

$78(82,1 \%)$

$$
31(24,4 \%)
$$

0,68

$0,35-1,31$

0,243

$4(4,2 \%)$

$91(95,8 \%)$

$(-)$

$127(100 \%)$

$2(2,1 \%)$

$93(97,9 \%)$
$(-)$

$127(100 \%)$

Ket. : RO (Rasio Odds), IK (Interval Kepercayaan)

Hasil analisis menggunakan uji chi-square, terdapat tiga variabel yang menunjukkan hubungan yang signifikan. Hal tersebut karena nilai $p$ pada analisis bivariat kurang dari 0,05. Variabel-variabel tersebut adalah jenis kelamin $(p=0,034)$, pekerjaan $(p=0,018)$ dan riwayat penyakit artritis reumatoid $(p=0,032)$. Variabel lain seperti usia, riwayat kehamilan dan riwayat diabetes melitus (RO: 0,68, IK 95\%=0,35 - 1,31, $p=0,243$ ) memiliki nilai $p$ lebih dari 0,05 sehingga tidak menunjukkan hubungan yang signifikan terhadap STK.

Pada analisis ini, terlihat bahwa variabel jenis kelamin, riwayat artritis reumatoid bersama pekerjaan tidak bermakna secara statistik, tetapi variabel pekerjaan sebagai ibu rumah tangga dibandingkan dengan PNS (RO: $3,34$, IK $95 \%=1,36-8,24, p=0,009)$ memiliki nilai $p$ kurang dari 0,05 sehingga variabel tersebut berhubungan dengan kejadian STK dan bermakna secara statistik. Pekerjaan sebagai ibu rumah tangga memiliki nilai RO lebih dari 1 dengan tidak mengandung nilai 1 pada nilai IK 95\% sehingga ibu rumah tangga merupakan faktor risiko independen terhadap kejadian STK. Ibu rumah tangga memiliki nilai $\mathrm{RO}$ sebesar 3,34 sehingga ibu rumah tangga meningkatkan kejadian STK sebesar 3,3 kali lipat dibanding pekerjaan lain.

Tabel 4. Analisis multivariat antara variabel jenis kelamin, pekerjaan dan artritis reumatoid dengan kejadian STK

\begin{tabular}{lccc}
\hline \multicolumn{1}{c}{ Variabel } & OR & IK 95\% & $\boldsymbol{p}$ \\
\hline $\begin{array}{l}\text { Jenis kelamin } \\
\text { - Laki-laki }\end{array}$ & Ref & & \\
Perempuan & 1,40 & $0,76-2,58$ & 0,278 \\
\hline Artritis Reumatoid & 0,00 & 0,00 & 0,999 \\
\hline Pekerjaan & Ref & & \\
- PNS & 0,40 & $0,76-2,95$ & 0,247 \\
- Swasta & 1,47 & $0,49-4,39$ & 0,488 \\
- $\quad$ Ibu Rumah & 3,34 & $1,36-8,24$ & $0,009^{*}$ \\
- Pedagang & 1,83 & $0,49-6,75$ & 0,363 \\
\hline
\end{tabular}

Ket.: RO (Rasio Odds), IK (Interval Kepercayaan) 


\section{PEMBAHASAN}

Hasil penelitian menunjukkan bahwa diabetes melitus tidak memiliki hubungan yang signifikan terhadap kejadian sindroma terowongan karpal (RO: 0,68, IK 95\%=0,35 - 1,31, $p=0,243$ ). Hasil ini sesuai dengan penelitian terdahulu yang menyebutkan bahwa diabetes melitus bukan merupakan faktor risiko independen dari STK (RO: 0,99, IK 95\%=0,66 - 1,47, $p=0,946) .{ }^{7}$ Pernyataan tersebut juga didukung oleh penelitian yang menyebutkan bahwa diabetes melitus tidak berhubungan dengan STK. ${ }^{9}$

Hal ini berbeda dengan penelitian lain yang menyebutkan bahwa faktor risiko dari STK adalah diabetes melitus (RO: 1,51). ${ }^{8}$ Perbedaan hasil penelitian disebabkan oleh perbedaan metode, yaitu kasus kontrol dan perbedaan jumlah sampel yang signifikan. Mekanisme terjadinya STK pada pasien diabetes terkait dengan mekanisme neuropati, dimana saat hiperglikemi tidak terkontrol, terjadi glikosilasi yang menyebabkan kekakuan dan penebalan protein tendon dari terowongan karpal. ${ }^{10}$

Berdasar hasil analisis multivariat, variabel pekerjaan sebagai ibu rumah tangga (RO: 3,34 , IK 95\%=1,36 - 8,24, $p=0,009)$ memiliki nilai $p$ kurang dari 0,05 sehingga memiliki hubungan yang signifikan terhadap kejadian STK. Hasil tersebut didukung oleh penelitian yang menyebutkan bahwa STK berhubungan dengan pekerjaan, khususnya pada pekerjaan yang memerlukan pergerakan tangan yang repetitif. ${ }^{11}$

Studi tentang ICCP (intracarpal canal pressure) menyatakan bahwa posisi tangan saat istirahat ICCP berada dalam posisi terendah dan saat tangan melakukan fleksi atau ekstensi ICCP berada dalam posisi tertinggi. Hasil tersebut menunjukkan bahwa pergerakan tangan yang banyak dan repetitif menyebabkan pembengkakan dan meningkatnya ICCP pada terowongan karpal. ${ }^{11}$

Pekerjaan sebagai ibu rumah tangga merupakan faktor risiko independen terhadap kejadian STK dimana variabel tersebut memiliki nilai $\mathrm{RO}$ sebesar 3,34 sehingga ibu rumah tangga meningkatkan kejadian STK sebesar 3,3 kali lipat dibanding pekerjaan lain.

\section{KESIMPULAN}

Berdasarkan hasil penelitian ini dapat disimpulkan bahwa tidak terdapat hubungan antara diabetes melitus terhadap kejadian sindroma terowongan karpal di RS Bethesda Yogyakarta.

\section{DAFTAR PUSTAKA}

1. Rambe, A. S. 2004. Sindrom Terowongan Karpal (Carpal Tunnel Syndrome). Universitas Sumatera Utara.

2. Tana, L. 2003. Sindrom Terowongan Karpal pada Pekerja: Pencegahan dan Pengobatannya. Jurnal Kedokteran Trisakti Vol. 22 No. 3. p. 99-104.

3. American Academy of Orthopaedic Surgeons. 2008. Clinical Practice Guideline on the Treatment of Carpal Tunnel Syndrome.

4. LeBlanc, K. E. \& Cestia, W. 2011. Carpal Tunnel Syndrome. American Family Physician Vol. 83 No. 8. p. 952-958.

5. Gustian, R. 2006. Diagnosis dan Klasifikasi Diabetes Melitus. Dalam: Sudoyo, A. W. et al., ed. Buku Ajar Ilmu Penyakit Dalam Jilid III, edisi IV. Jakarta : Departemen Ilmu Penyakit Dalam FK UI. p. 1857-1859.

6. Fitzgibbons, P. G., \& Weiss, A. C. 2008. Hand Manifestations of Diabetes. Journal of Hand Surgery Vol. 33, issue 5. p. 771-775. 
7. Hendriks, S. H., van Dijk, P. R., Groenier, K. H. et al. 2014. Type 2 Diabetes Seems Not to be a Risk Factor for the Carpal Tunnel Syndrome: A Case Control Study. BMC Musculoskeletal Disorders 2014, 15:346. p. 1-5.

8. Geoghegan, J. M., Clark, D. I., Bainbridge, L. C. et al. 2004. Risk Factors in Carpal Tunnel Syndrome. Journal of Hand Surgery. [Online]. Available from:

h t t p: / / jhs.sage pub.com / content/29/4/315 [Accessed $16 / 11 / 2014]$.

9. Becker, J., Nora, D. B., Gomes, I. et al. 2002. An evaluation of gender, obesity, age and diabetes mellitus as risk factors for carpal tunnel syndrome. Clinical Neurophysiology. [Online]. Available from :

http:/ / www.clinph-journal.com / article/S1388-2457(02)00201-8/ abstract [Accessed 3/10/2014].

10. Von Wartburg, L. 2007. Carpal Tunnel Syndrome a Common Cohort of Diabetes. Diabetes Health. $29^{\text {th }}$ June. Available from :

http:/ / diabeteshealth.com / $\mathrm{read} / 2007 / 06 / 29 / 5276 /$ carpaltunnel-syndrome-a-commoncohort-of-diabetes $/$ ? isComment $=1$ [Accessed 17/10/2014].

11. Rosati, P. 2009. Carpal Tunnel Syndrome - Is it Work-Related?. Options Inc. 